DOI https://doi.org/10.18551/rjoas.2018-09.15

\title{
THE EFFECT OF INFLATION, RUPIAH EXCHANGE RATE, BANK INDONESIA SHARIA CERTIFICATE, WORLD OIL PRICES, AND WORLD GOLD PRICES AGAINST THE PRICES DEVELOPMENT OF SHARES IN JAKARTA ISLAMIC INDEX
}

\author{
Ulum Muhammad Bahrul ${ }^{*}$, Susetyo Didik, Yuliana Sa'adah \\ University of Sriwijaya, Palembang, Indonesia \\ *E-mail: bahrulu1994@gmail.com
}

\begin{abstract}
The purpose of this study is to determine the effect of inflation, rupiah exchange rate, Bank Indonesia Sharia certificate, world oil prices, and world gold prices against the prices development of shares in Jakarta Islamic Index. In this study concluded that the inflation effect is negative and not significant to the development of stock price Jakarta Islamic Index. The value of the rupiah and Bank Indonesia Sharia certificate has a negative and significant impact on the development the price shares of Jakarta Islamic Index, while the world oil price and world gold price have a positive but not significant impact on development of the stock Jakarta Islamic Index.
\end{abstract}

\section{KEY WORDS}

Inflation, rupiah exchange rate, Bank Indonesia Sharia certificate, world oil prices, world gold prices, Jakarta Islamic Index.

The capital market is one of the instruments of today's economy has growth very rapidly. The capital market is an indicator of the economic progress of a country as well as support the economy of the century concerned. The capital market has an important role for the economy of a country because the capital markets perform two functions. The function of capital market the first is as a means for funding a business or as a means for companies to obtain funds from public investors. The function of capital market the second is a means for people to invest in financial instruments such as stock, bonds, mutual funds, and others (Rusbariand et al., 2012).

In Indonesia began to develop financial instruments based on Sharia such as Islamic bank, Islamic capital market, and commodity market Sharia. The initial step the development of the stock transactions in the Islamic capital market Indonesia is recorded by the presence of the Sharia of the Jakarta Islamic Index in July 2000. The Jakarta Islamic Index is a group of stocks that meet the instruments criteria of Islamic Sharia in the Indonesia capital market. Sharia stocks that become the constituents of the Jakarta Islamic Index consists of 30 stocks that are the most liquid Sharia shares and has a market capitalization of large. Business development is supported with a set of fatwa DSN MUI related to the industry of the Islamic capital market, namely the fatwa No. 05 of 2000 about buying and selling shares as well as in strengthen again in 2003 with issued his fatwa no 40 of the year 2003 regarding capital market and general guidelines for the implementation of Sharia principles in the capital market (Otoritas Jasa Keuangan, 2016).

The development of stock prices in capital market industry should respond seriously by investors, in practice in the field the investor should pay attention to all situation that will occur well it's definite situation and the situation uncertain special in a state of uncertain, an investor should be more carefull (Rusbariand et al., 2012).

A state that does not definitely indicate the presence of risks, in general the risks and grouped into two types, namely systematic risks and unsystematic risks. With respect to the importance of attention to macro-economic conditions with become part of the systematic risks, the market capital Sharia Indonesia that the performance of her reflected in the concept Jakarta Islamic Index was not able to avoid the presence of the risks. As known the development of oil prices of the world, the prices of gold in the world and variables indicator economic macro like the pace of the inflation up in the exchanges rate rupiah against the 
dollar at union. As well as the certificate bank Indonesia Sharia always fluctuates in every period so indicated influential on the investing in the market capital is one of the indicator economic growth of country (Padli, 2016).

Certainly also oil prices of the world, price of the gold and variables macro economy it would be reject progression for the investors to also took the decision important to instill capital in the market capital. The problem of being a discussion of this article are the influence of between the inflation, the exchange rate, the certificate bank Indonesia Sharia, the oil price of the world, and the price of gold against the development of stock price Jakarta Islamic Index.

\section{METHODS OF RESEARCH}

Used data in this study has a range of the time of January 2015 until December 2017. Data collected through the study namely the data collection directed to the research data and information through the good documents written and electronic paperwork can support writing process. The data collected from some of the website is www.idx.co.id, www.bi.go.id, and www.investing.com. This study applies double linear regression method with the form of the function as follows:

$$
\operatorname{LnY}=\alpha+\beta_{1} \operatorname{Ln} x_{1}+\beta_{2} \operatorname{Ln} x_{2}+\beta_{3} \operatorname{Ln} x_{3}+\beta_{4} \operatorname{Ln} x_{4}+\beta_{5} \operatorname{Ln} x_{5}+e
$$

Where:

$Y=$ The development of stock price Jakarta Islamic Index;

Ln = Natural Logarithm;

$x_{1}=$ Inflation;

$x_{2}=$ The exchange rate rupiah;

$x_{3}=$ The certificate bank Indonesia Sharia;

$x_{4}=$ Oil price of the world;

$x_{5}=$ The price gold of the world;

$a=$ Constanta;

$\beta_{1}, \beta_{2}, \beta_{3}, \beta_{4}, \beta_{5}, \beta_{6}=$ The coefficient of regressing;

$e=$ Error Term

Data is transformed into the form of the natural logarithm (Ln) aims to data variation from the average of the mean thus obtained variants which a small in addition, the transformation is done so that the model generated is good and not having problems multicollinearity, autocorrelation, heteroscedasticity, and normality (Purwanto, 2012).

The results of linear regression double in the can are as follow:

Table 1 - The results of the regressions

Dependent Variable: LOG(JII)

Method: Least Squares

Date: 07/22/18 Time: 20:34

Sample: 2015M01 2017M12

Included observations: 36

\begin{tabular}{lllll}
\hline \hline Variable & Coefficient & Std. Error & t-Statistic & Prob. \\
\hline \hline LOG(INFLASI) & -0.004213 & 0.027150 & -0.155182 & 0.8777 \\
LOG(NILAI_TUKAR) & -1.533195 & 0.291600 & -5.257869 & 0.0000 \\
LOG(SBIS) & -0.462900 & 0.107335 & -4.312666 & 0.0002 \\
LOG(HARGA_MINYAK_DUNIA) & 0.016054 & 0.053989 & 0.297362 & 0.7682 \\
LOG(HARGA_EMAS_DUNIA) & 0.280937 & 0.149318 & 1.881470 & 0.0696 \\
C & 19.90135 & 3.686281 & 5.398760 & 0.0000 \\
\hline \hline R-squared & 0.861566 & Mean dependent var & 6.529035 \\
Adjusted R-squared & 0.838494 & S.D. dependent var & 0.084350 \\
S.E. of regression & 0.033899 & Akaike info criterion & -3.779879 \\
Sum squared resid & 0.034473 & Schwarz criterion & -3.515959 \\
Log likelihood & 74.03781 & Hannan-Quinn criter. & -3.687764 \\
F-statistic & 37.34196 & Durbin-Watson stat & 1.653294 \\
Prob(F-statistic) & 0.000000 & & & \\
\hline \hline
\end{tabular}


Test Statistics. The calculations carried out to measure to proportion or percentage of variation total dependent variable that is able to explained by the regression model. $R^{2}$ in the regression of 0.861566 . This means that the variable price development the shares of Jakarta Islamic Index $(Y)$ can be explained by the variables of inflation $\left(x_{1}\right)$, rupiah exchange rate $\left(x_{2}\right)$, Bank Indonesia Sharia certificate $\left(x_{3}\right)$, world oil prices $\left(x_{4}\right)$, and the world price of gold $\left(x_{5}\right)$ amounting 86,15 percent of the rest is explained by other variables outside of the function regression.

The $t$ test was conducted to determine the influence of determine the influence of independent variables on the dependent variable in the partial T-Statistic variable inflation of 0.8777 because the probability of T-Statistics is greater than 0.05 then the hypothesis $(\mathrm{Ho})$ is rejected means the partial inflation and no significant negative effect on the development of stock prices in Jakarta Islamic Index. The coefficient of regressing inflation of 0.004213 showed that every rising inflation amounting 1 percent it will lose of stock price Jakarta Islamic Index of 0.004213 percent.

Based on the results of reckoning on the table 1 in get results t-statistic variable exchange rate rupiah of 0.0000 because the probability of t-statistics smaller than 0.05 then hypothesis (Ho) accepted means in partial exchange rate rupiah influential negative and significant against the development of stock price Jakarta Islamic Index. The coefficient of regressing exchange rate rupiah of -1.533195 showed that every rise in the exchange rate rupiah amounting to 1 percent then will lose of stock price Jakarta Islamic Index of 1.533195 percent.

The table 1 showed that the value of t-statistic variable certificate bank Indonesia concept of 0.0002 because the probability of $\mathrm{t}$-statistic smaller than 0.05 then hypothesis $(\mathrm{Ho})$ in received means in partial certificates bank Indonesia Sharia influential negative and significant against the development of stock price Jakarta Islamic Index. The regression coefficient of bank Indonesia Sharia influential negative and significant against the development of stock price Jakarta Islamic Index. The regression coefficient of bank Indonesia Sharia certificate of -0.462900 shows that any increase in bank Indonesia Sharia certificate amounting 1 percent then it will lower the price of shares in Jakarta Islamic Index amounting 0.462900 percent.

The results of $t$ - statistics variables world oil price amounted to 0.7682 , this can be seen in table 1 because the probability of t-statistics is greater than 0.05 then the hypothesis $(\mathrm{Ho})$ rejected means in a partial world oil prices have a positive but not significant impact on the development of stock price in Jakarta Islamic Index. Regression of world oil prices amounting 0.016054 shows that every increase in world oil price amounting 1 percent then it will increase the price of the shares of Jakarta Islamic Index. Amounting 0.002740 percent.

Based on the table 1 obtained results of $t$ - statistics variable price gold world of 0.0696 . Because the probability of t-statistics is greater than 0.05 then the hypothesis $(\mathrm{Ho})$ is rejected means the partial world gold prices have a positive but not significant impact on the development of stock prices in Jakarta Islamic Index. The regression coefficient of the world price gold amounted to 0.280937 show that any increase in world gold price amounted 1 percent would raise the price the shares of Jakarta Islamic Index.

Statistical Test $F$. This test aims to determine whether the independent variables simultaneously or together effect the dependent variable significantly. In table 1 , it is seen that the probability of $F$ statistics of 0.0000 with $95 \%$ confidence level $(\alpha=0.05)$ then the null hypothesis of research is rejected because the value of the probability of $F$ statistics is smaller than $\alpha$, which means the independent variable (inflation, exchange rate rupiah, bank Indonesia Sharia certificate, world oil prices, and the world price of gold) together have a significant effect on the development of stock prices in Jakarta Islamic Index.

Multicollinearity Test. Test multicollinearity it can be seen from the value of tolerance and variance inflation factor. Tolerance measure variable free elected that cannot in explain by variable free. So, the value of tolerance low the same with the value of variance inflation factor high (because variance inflation factor $=1 /$ tolerance) and show the colinearity high. The value of cut off the common in life is the value of tolerance 0.10 or value variance inflation factor that was under this 10 . 
Table 2 - Test results multicollinearity test

Variance Inflation Factors

Date: 07/24/18 Time: 00:06

Sample: 2015M01 2017M12

Included observations: 36

\begin{tabular}{llll}
\hline \hline & Coefficient & Uncentered & Centered \\
Variable & Variance & VIF & 2.077058 \\
\hline \hline LOG(INFLASI) & 0.000737 & 52.37008 & 1.812303 \\
LOG(NILAI_TUKAR) & 0.085031 & 240787.3 & 2.996153 \\
LOG(SBIS) & 0.011521 & 1216.074 & 1.819315 \\
LOG(HARGA_MINYAK_DUNIA) & 0.002915 & 1371.406 & 2.813403 \\
LOG(HARGA_EMAS_DUNIA) & 0.022296 & 35293.47 & NA \\
C & 13.58867 & 425713.9 & \\
\hline \hline
\end{tabular}

The results of the test of multicollinearity, can be seen in table 2 column centered VIF. The value of the variance inflation, exchange rate rupiah, Bank Indonesia Sharia certificate, world oil prices and the world price of gold each is 2.077058, 1.812303, 2.996153, 1819315 and 2.813403. Because the VIF value of the fifth variable does not exist which is greater than 10 then it can be said did not happen multicollinearity on the five independent variables.

Autocorrelation Test. Autocorrelation test is very useful to identify the problem of autocorrelation not only on the degree of the first (first order) but also used on the level of degree. Autocorrelation test can be seen from the probability of chi-square. If the probability of chi- square is $>5 \%$ then Ho failed to be rejected and can be concluded the data there is no autocorrelation and it is better if probability of chi- square is $<5 \%$ then the Ha fails is rejected or there is autocorrelation.

Table 3 - The results autocorrelation test

Breusch-Godfrey Serial Correlation LM Test:

\begin{tabular}{llll}
\hline \hline F-statistic & 0.519830 & Prob. F(2,28) & 0.6002 \\
Obs*R-squared & 1.288849 & Prob. Chi-Square(2) & 0.5250 \\
\hline \hline
\end{tabular}

From the table above it is known that the value of obs* $R$-square of 1.288849 and a probability value of chi- square 0.5250 greater than the value of 0.05 . Because the probability value of chi- square $>\alpha=5 \%$, Then the model id freed from the problem of autocorrelation then $\mathrm{Ho}$ is accepted it can be concluded that the data there is no problem of autocorrelation. With the passing of the autocorrelation test then there is no relationship between members of series of observations sorted according to time and space.

Heteroscedasticity Test. Heteroscedasticity test aims to test whether in the regression model occurs the dissimilarity variants from one observation to the other observations. A good regression model is if it does not happen heteroscedasticity. To detect the data have problems of heteroscedasticity or not, namely if the probability of obs ${ }^{*} R$-squared $>0.05$ then the data is no there heteroscedasticity. So, on the other hand, if the probability of obs* $R$ Square $<0.05$ then the data are heteroscedasticity.

Table 4 - The test results Heteroscedasticity

Heteroscedasticity Test: Breusch-Pagan-Godfrey

\begin{tabular}{llll}
\hline \hline F-statistic & 0.688481 & Prob. F(5,30) & 0.6359 \\
Obs*R-squared & 3.705671 & Prob. Chi-Square(5) & 0.5925 \\
Scaled explained SS & 2.095750 & Prob. Chi-Square(5) & 0.8357 \\
\hline \hline
\end{tabular}

From the table above it is known that the value of obs* $R$-Square is 3.705671 and the probability of the chi-square of 0.5925 greater than a value of 0.05 because the probability value of chi- square is $>5 \%$ then in this case Ho is accepted so, it can be concluded that the data are homoscedasticity after the tests are performed the Breusch-Pagan-Godfrey. With the passing of the test of heteroscedasticity then the regression model can be said 
homoscedasticity namely variance from residual of one observation to the observation of others remain.

Normality Test. To be able to know the normal presence or absence of the factor of destruction is done with the J-B test (Jarque-Bera Test). This test using the results of estimation residual and chi- square probability distribution.

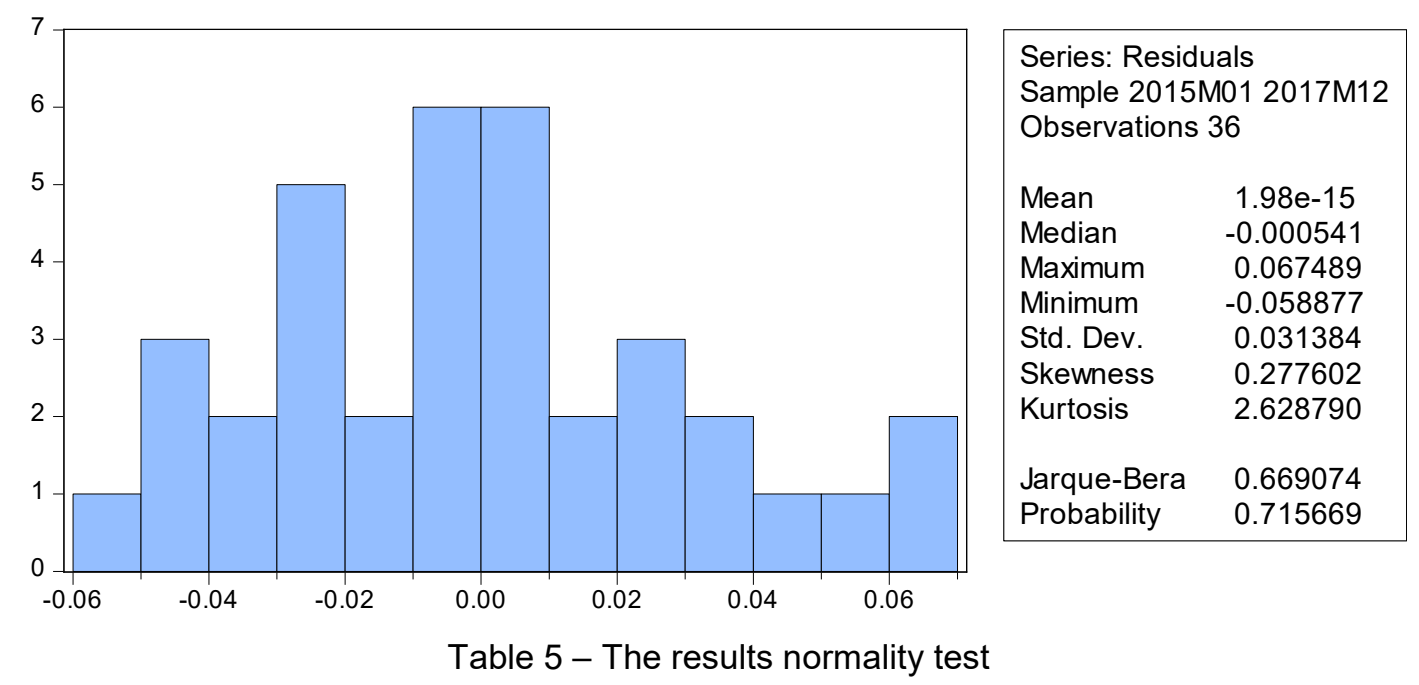

Hypothesis decision making:

- Ho: If the value of probability JB $>0.05$ it can be said that the residual distribution is normal;

- $\mathrm{H} 1$ : If the value of probability JB $<0.05$ it can be said that the residual distribution is not normal.

From the table 5 it can be seen that the value of the probability of 0.715660 this means the value of probability is $>0.05$ it can be said that data distribution is normal.

The results of the estimation and classical assumption test that have been done it turns out that the results of the estimation of the development of stock price Jakarta Islamic Index there is no multicollinearity, heteroscedasticity, autocorrelation, and normal distribution so that the results of such testing can be apply more.

\section{CONCLUSION}

Inflation, exchange rate rupiah, Bank Indonesia Sharia, certificate world oil prices, and world gold prices together have a significant effect on development of the stock price Jakarta Islamic Index. The test results individually show that the variable of inflation has a negative and significant impact on the development of the stock price Jakarta Islamic Index. Variable the value of the rupiah and bank Indonesia Sharia certificate negative and significantly to the development of the stock price Jakarta Islamic Index. The variable world oil prices and the world price gold negatively and not significant to the development of the stock price Jakarta Islamic Index. The value of the coefficient of determination $\left(R^{2}\right)$ of 0.861566 shows that the variation of the inflation, exchange rate rupiah, bank Indonesia Sharia certificate, world oil price, and gold price as a whole is able to explain 86,15 percent of the variation in the development of the stock price Jakarta Islamic Index.

From the fifth independent variables used in this study, the variables that have the most impact on the development of the stock price Jakarta Islamic Index is a variable the value of the rupiah and bank Indonesia Sharia certificate. This can be seen from the coefficient of the variable exchange rate of the rupiah and the coefficient of bank Indonesia Sharia certificate on the results of the regression that has the most value compared to other variables. This means that any change in the rupiah exchange rate will affect the development of the stock price Jakarta Islamic Index. From this research it can be concluded that the certificate of bank Indonesia Sharia be an alternative of investment based on Sharia 
in addition to the stock of Jakarta Islamic Index. This can be seen from the results of the regression show that the development of the stock price Jakarta Islamic Index is influenced by a certificate of bank Indonesia Sharia and any change in the price of united state dollar will have an impact on stock price in Indonesia.

\section{REFERENCES}

1. Bank Indonesia. (2008). Sertifikat Bank Indonesia Sharia.

2. Beik, I. S., \& Fatmawati, S. W. (2014). Pengaruh Indeks Harga Saham Sharia Internasional Dan Variabel Makro Ekonomi Terhadap Jakarta Islamic Index. Al-lqtishad: Jurnal IImu Ekonomi Sharia, 6(2), 155-178.

3. Boediono. (2011). Ekonomi Makro. Yogyakarta: BPFE-Yogyakarta.

4. Fahmi, I. (2012). Analisis Kinerja Keuangan: Panduan bagi Akademisi, Manajer, dan Investor untuk Menilai dan Menganalisis Bisnis dari Aspek Keuangan. Bandung: Alfabeta.

5. Khalwaty. (2010). Inflasi dan Solusinya. Jakarta: PT Gramedia Pustaka Utama.

6. Lutfiana, I. M. (2015). HARGA SAHAM KELOMPOK JAKARTA ISLAMIC INDEX DI INDONESIA PERIODE 2007-2015.

7. Malik, A. D. (2017). Analisa Faktor - Faktor Yang Mempengaruhi Minat Masyarakat Berinvestasi Di Pasar Modal Sharia Melalui Bursa Galeri Investasi UISI. Jurnal Ekonomi Dan Bisnis Islam, 3(1), 61-84.

8. Natsir, M. (2014). Ekonomi Moneter dan Kebanksentralan. Jakarta: Mitra Wacana Media.

9. Otoritas Jasa Keuangan. (2016). Sinergi Menuju Pasar Modal Sharia Sinergi Menuju Pasar Modal Sharia yang Lebih Besar dan Berkembang Perkembangan.

10. Padli, I. N. (2016). Bisnis dan Investasi Sharia. https://doi.org/10.13140/RG.2.1.4195.6084

11. Purwanto, E. (2012). Metodologi Penelitian Kuantitatif. Yogyakarya: Pustaka Pelajar.

12. Rusbariand, S. P., Masodah, Riskayanto, \& Herawati, S. (2012). Analisis pengaruh tingkat inflasi, harga minyak dunia, harga emas dunia, dan kurs rupiah terhadap pergerakan jakarta islamic index di bursa efek Indonesia. Prosiding Seminar Nasional, 724-740.

13. Sholeh. (2011). The Dinar Way. Jakara: Qultum Media.

14. Utoyo, N. N. (2016). Pengaruh tingkat inflasi, suku bunga, harga emas dunia, dan kurs rupiah pada jii, 5(c).

15. Witjaksono, A. A. (2010). Analisis Pengaruh Tingkat Suku Bunga SBI, Harga Minyak Dunia, Harga Emas Dunia, Kurs Rupiah, Indeks Nikkei 225, dan Indeks Dow Jones terhadap IHSG (studi kasus pada IHSG di BEI selama periode 2000-2009). USU Repository, 4(1), 134. 